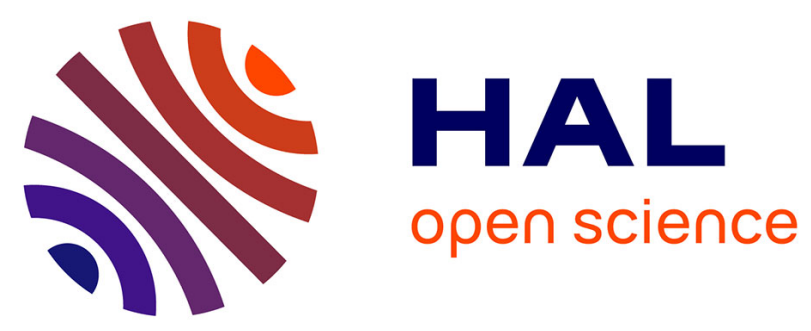

\title{
A series of 38 novel germline and somatic mutations of NIPBL in Cornelia de Lange syndrome
}

Mathilde Nizon, Marcia Henry, Caroline Michot, Clarisse Baumann, Anne Bazin, Bettina Bessieres, Sophie Blesson, Marie-Pierre Cordier-Alex, Albert David, Andrée Delahaye-Duriez, et al.

\section{To cite this version:}

Mathilde Nizon, Marcia Henry, Caroline Michot, Clarisse Baumann, Anne Bazin, et al.. A series of 38 novel germline and somatic mutations of NIPBL in Cornelia de Lange syndrome. Clinical Genetics, 2016, 89 (5), pp.584-589. 10.1111/cge.12720 . hal-01255844

HAL Id: hal-01255844

https://hal-univ-rennes1.archives-ouvertes.fr/hal-01255844

Submitted on 6 Jun 2016

HAL is a multi-disciplinary open access archive for the deposit and dissemination of scientific research documents, whether they are published or not. The documents may come from teaching and research institutions in France or abroad, or from public or private research centers.
L'archive ouverte pluridisciplinaire HAL, est destinée au dépôt et à la diffusion de documents scientifiques de niveau recherche, publiés ou non, émanant des établissements d'enseignement et de recherche français ou étrangers, des laboratoires publics ou privés. 


\section{A series of 38 novel germline and somatic mutations of NIPBL in Cornelia}

\section{de Lange syndrome}

Mathilde Nizon ${ }^{1}$, Marcia Henry ${ }^{1}$, Caroline Michot ${ }^{1}$, Clarisse Baumann ${ }^{2}$, Anne Bazin ${ }^{3}$, Bettina Bessières ${ }^{1}$, Sophie Blesson $^{4}$, Marie-Pierre Cordier-Alex ${ }^{5}$, Albert David ${ }^{6}$, Andrée Delahaye-Duriez ${ }^{7}$ Anne-Lise Delezoïde ${ }^{2}$, Anne Dieux-Coeslier ${ }^{8}$, Martine Doco-Fenzy ${ }^{9}$, Laurence Faivre ${ }^{10}$, Alice Goldenberg ${ }^{11}$, Valérie Layet $^{12}$, Philippe Loget $^{13}$, Sandrine Marlin ${ }^{1}$, Jelena Martinovic ${ }^{1}$, Sylvie Odent ${ }^{14}$, Laurent Pasquier ${ }^{14}$, Ghislaine Plessis ${ }^{15}$, Fabienne Prieur $^{16}$, Audrey Putoux ${ }^{5}$, Marlène Rio ${ }^{1}$, Hervé Testard ${ }^{17}$, Jean-Paul Bonnefont ${ }^{1}$ and Valérie Cormier-Daire ${ }^{1}$

1. Département de Génétique, Université Paris Descartes-Sorbonne Paris Cité, INSERM UMR1163, Institut IMAGINE, Hôpital Necker-Enfants Malades, Paris, France.

2. Département de Génétique, CHU Robert Debré, 75019 Paris

3. Département de Génétique, CH René Dubos, Pontoise, France

4. Service de Génétique, CHRU Tours, Hôpital Bretonneau, Tours, France

5. Service de Génétique Clinique, Hospices Civils de Lyon, Bron, France

6. Service de Génétique Médicale, CHU, Nantes, France

7. Service de Génétique, CHU Paris Seine-Saint-Denis, Hôpital Jean Verdier, Bondy, France

8. Service de Génétique Clinique, CHRU de Lille, Hôpital Jeanne de Flandre, Lille, France

9. Service de Génétique, CHU de Reims, Hôpital Maison Blanche, EA 3801 SFR CAP-Santé, Reims, France

10. Centre de Génétique, CHU de Dijon, Dijon, France

11. Département de Génétique, CHU, Rouen, France

12. Service de Génétique Médicale, GH du Havre, Hôpital Jacques Monod, Le Havre, France

13. Service d'anatomie et cytologie pathologiques, Hôpital Pontchaillou, Université de Rennes 1, CHU, Rennes, France

14. Service de Génétique Clinique, CHU Rennes, Hôpital Sud, Rennes, France

15.Service de Génétique Médicale, CHU Clémenceau, Caen, France

16. Service de Génétique Clinique, CHU de Saint-Etienne, Hôpital Nord, Saint-Priest-en-Jarez, France

17. Département de Pédiatrie, CHU Grenoble, Grenoble, France 


\section{Corresponding author}

Valérie Cormier-Daire, MD-PhD

Département de GénétiqueUniversité Paris Descartes, Sorbonne Paris Cité, INSERM UMR1163

Institut IMAGINE

Hôpital Necker-Enfants Malades

Paris, France.

33144495163

valerie.cormier-daire@inserm.fr

\section{Acknowledgements}

We thank our colleagues for referring patients, and the patients and their families for participating in this study.

\section{Conglict of interest statement}

The authors declare that they have no competing interests.

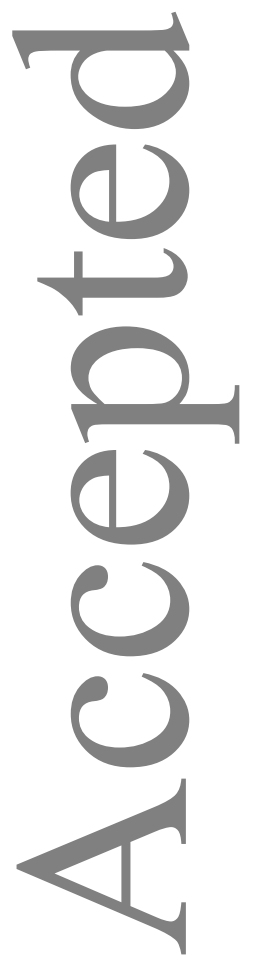




\section{ABSTRACT}

Cornelia de Lange syndrome is a multisystemic developmental disorder mainly related to de novo heterozygous NIPBL mutation. Recently, NIPBL somatic mosaicism has been highlighted through buccal cell DNA study in some patients with a negative molecular analysis on leukocyte DNA.

Here, we present a series of 38 patients with a Cornelia de Lange syndrome related to an heterozygous NIPBL mutation identified by Sanger sequencing. The diagnosis was based on the following criteria: 1) intrauterine growth retardation and postnatal short stature, 2) feeding difficulties and/or gastro-oesophageal reflux, 3) microcephaly, 4) intellectual disability and 5) characteristic facial features.

We identified 37 novel NIPBL mutations including 34 in leukocytes and three in buccal cells only. All mutations shown to have arisen de novo when parent blood samples were available. The present series confirms the difficulty in predicting the phenotype according to the NIPBL mutation. Until now, somatic mosaicism has been observed for twenty cases which does not seem to be consistently associated with a milder phenotype. Besides, several reports support a postzygotic event for those cases.

Considering these elements, we recommend a first-line buccal cell DNA analysis in order to improve gene testing sensitivity in Cornelia de Lange syndrome and genetic counseling.

Key words : Cornelia de Lange syndrome, NIPBL, somatic mosaicism, buccal cells 


\section{INTRODUCTION}

Cornelia de Lange syndrome [MIM \#122470, 300590, 610759, 300882, 614701] is a rare and severe multisystemic developmental disorder. Main clinical features include intrauterine growth retardation and postnatal short stature, microcephaly, limb defects ranging from brachydactyly to agenesia, characteristic facial features - arched eyebrows, synophrys, long philtrum and thin upper lip -, hirsutism, feeding difficulties, heart or urogenital malformation, hearing loss and variable degree of intellectual disability ${ }^{1}$.

Five genes have been identified so far in this syndrome. A heterozygous NIPBL [MIM \#608667] mutation is observed in about $60 \%$ of the patients ${ }^{2-4}$. The four other genes, SMC1A [MIM \#300040], SMC3 [MIM \#606062], HDAC8 [MIM \#300269] and RAD21 [MIM \#606462], represent about 10\% of identified

mutations ${ }^{5-7}$. While a small fraction of cases are inherited, majority of them results from de novo events. All these genes encode proteins involved in the cohesin complex, which is decisive for cell division and gene expression regulation. Recently, NIPBL somatic mosaicism has been highlighted through buccal cell DNA study in some patients with a negative molecular analysis on leukocyte DNA ${ }^{8}$.

\section{MATERIALS AND METHODS}

Here, we present a series of thirty-eight patients with a Cornelia de Lange syndrome caused by an heterozygous NIPBL mutation. Patients were recruited through national collaboration. The diagnosis of Cornelia de Lange syndrome was approved before molecular investigations based on the following criteria: 1) intrauterine growth retardation and postnatal short stature 2) feeding difficulties and/or gastro-oesophageal reflux 3) microcephaly, 4) intellectual disability and 5) characteristic facial features (see table 1). The study was approved by our hospital ethics board. Written informed patients and parent consents were obtained prior to genetic investigation.

NIPBL was analysed in first-line in all patients referred to our molecular genetics laboratory. DNA was isolated from leukocytes using the Puregene Blood Core Kit B (Qiagen), the Autopure automate (Qiagen) or the extraction blood kit Nucleon Bacc3 (GE Healthcare). DNA was additionally extracted from buccal cells in five patients with the Oragene saliva DNA collection Kit and according to the PrepIT protocol (DNA Genotek). cDNA was isolated from PAXgene blood RNA tubes (Qiagen) by a standard procedure for three patients with an intronic mutation. NIPBL coding region (GeneBank NG_006987.1) was sequenced with intronic primers designed by Primer3 Input (http://bioinfo.ut.ee/primer3-0.4.0/) and using the Big Dye Terminator cycle sequencing kit v3 (Applied Biosystems). Sequences were analysed on a 3130 or 3500 Genetic Analyser 
sequencing machine (Applied Biosystems).

\section{RESULTS}

Among these thirty-eight patients, we identified thirty-four novel NIPBL mutations in leukocytes and three novel NIPBL mutations in buccal cells only. To note that nine saliva samples have been tested among NIPBL negative patients on leukocytes. Mutations included six nonsense mutations, eighteen frame shifts, six intronic mutations and seven missense mutations (see table 1). The c.5329-15A>G intronic mutation was identified in two unrelated probands. Patients 2, 17 and 26 had a distinct novel mutation only present in buccal cells and undetectable in leukocytes by Sanger sequencing. All mutations were shown to have arisen de novo when parent blood samples were available for DNA study. The missense mutations were predicted as damaging using Polyphen and Alamut software. The intronic mutations were predicted to alter a donor or acceptor splicing site according to the Human Splicing Finder predicting splicing software. To analyse the effect of intronic mutations, namely the c.64+2T>A, c.772-7_772-4delinsA and c.5329-15A>G mutations, we performed NIPBL cDNA analysis on patients 25, 27 and 29 RNA extracted from leukocytes. These mutations were found to respectively cause skipping of exon 2 containing the ATG translation initiation codon, partial retention of intron 7 leading to a frame shift with premature stop codon, and in frame deletion with exon 28 skipping responsible for the exclusion of thirty-three amino acids in the conserved HEAT domain H1 of the protein (data not shown). Finally, DNA extracted from buccal cells were tested in three patients with a known NIPBL mutation on leukocytes. The mutation was confirmed in the three buccal cell samples (data not shown).

\section{DISCUSSION}

Until now, over 300 distinct mutations have been reported in NIPBL (literature and our present series) including a proven somatic mosaicism for seventeen ones. Among them, 60\% (196/325) are nonsense mutations, frame shifts or rearrangements, 16\% (52/325) are splicing mutations and 24\% (77/325) are missense mutations. All type of mutations have also been observed in patients with a somatic mosaicism. Mutations are spread all over the gene except for exons 13 and 16 as previously discussed, and most of them seem to be unique ${ }^{4}$.

To date, various attempts have failed to bring out a reliable phenotype-genotype correlation in patients with an NIPBL mutation ${ }^{9,10}$. Indeed, whereas a NIPBL mutation usually leads to a more severe phenotype than a mutation in one of the other genes involved in Cornelia de Lange syndrome, unrelated probands with a similar NIPBL mutation can have a severe, a classic or a mild phenotype ${ }^{11,12}$. The present series confirms the difficulty 
in predicting the phenotype according to the NIPBL mutation. To the same extent, a somatic mosaicism does not seem to be consistently associated with a milder phenotype. In this report, the three patients with somatic NIPBL mutation presented with the usual features namely short stature, microcephaly, feeding difficulty, brachymetacarpy and mild to moderate intellectual disability. Facial dysmorphism was also suggestive of the disease. However, additional reports of somatic NIPBL mosaicism is required to exclude a possible genotypephenotype correlation. Other events are probably involved in the pathophysiology of the disease supporting the wide range of severity.

Recently, buccal cell analysis has shown its relevance for the molecular study of patients presenting with a Cornelia de Lange syndrome. Thereby, mutation in buccal cells has been identified in probands negative for NIPBL mutation in leukocytes ${ }^{8,13}$. Other reports support a postzygotic event. Indeed, somatic mosaicism has already been identified on leukocytes for four different NIPBL mutations, namely a large intragenic deletion, a frame shift, a nonsense and a missense mutation, by array-comparative genomic hybridisation, pyrosequencing and exome sequencing, respectively ${ }^{14-17}$. Almost $50 \%$ of patients negative for NIPBL mutation in leucocytes are predicted to have a somatic mosaicism ${ }^{8}$ Embryological data are in agreement with these results. Indeed, oral epithelium derives from embryonic ectoderm, which is also the precursor for the neural tube leading to brain development. Besides, buccal cells can be performed less invasively than fibroblasts. Considering these elements, we recommend a first-line buccal cell DNA analysis in order to easily improve gene testing sensitivity in Cornelia de Lange syndrome. The exome sequencing extent will probably lead to a better detection of low levels of mosaicism in different cell types, setting out more arguments to refine genetic counseling, cutting down the germline mosaicism likelihood ${ }^{18}$.

To conclude, NIPBL remains the major gene responsible for Cornelia de Lange syndrome either by germline or somatic mutation. The high frequency of somatic mosaicism supports the need for buccal cell DNA analysis. Further investigations should help understanding whether this is a disease or gene specific mechanism, or a more generalised one. 


\section{REFERENCES}

1 Jackson L, Kline AD, Barr MA, Koch S. de Lange syndrome: a clinical review of 310 individuals. Am J Med Genet 1993; 47: 940-946.

2 Krantz ID, McCallum J, DeScipio C et al. Cornelia de Lange syndrome is caused by mutations in NIPBL, the human homolog of Drosophila melanogaster Nipped-B. Nat Genet 2004; 36: 631-635.

3 Tonkin ET, Wang T-J, Lisgo S, Bamshad MJ, Strachan T. NIPBL, encoding a homolog of fungal Scc2-type sister chromatid cohesion proteins and fly Nipped-B, is mutated in Cornelia de Lange syndrome. Nat Genet 2004; 36: 636-641.

4 Mannini L, Cucco F, Quarantotti V, Krantz ID, Musio A. Mutation spectrum and genotype-phenotype correlation in Cornelia de Lange syndrome. Hum Mutat 2013; 34: 1589-1596.

5 Deardorff MA, Kaur M, Yaeger D et al. Mutations in cohesin complex members SMC3 and SMC1A cause a mild variant of cornelia de Lange syndrome with predominant mental retardation. Am J Hum Genet 2007; 80: 485-494.

6 Deardorff MA, Bando M, Nakato R et al. HDAC8 mutations in Cornelia de Lange syndrome affect the cohesin acetylation cycle. Nature 2012; 489: 313-317.

7 Deardorff MA, Wilde JJ, Albrecht M et al. RAD21 mutations cause a human cohesinopathy. Am J Hum Genet 2012; 90: 1014-1027.

8 Huisman SA, Redeker EJW, Maas SM, Mannens MM, Hennekam RCM. High rate of mosaicism in individuals with Cornelia de Lange syndrome. J Med Genet 2013; 50: 339_ 344.

9 Borck G, Redon R, Sanlaville D et al. NIPBL mutations and genetic heterogeneity in Cornelia de Lange syndrome. J Med Genet 2004; 41: e128.

10 Gillis LA, McCallum J, Kaur M et al. NIPBL mutational analysis in 120 individuals with Cornelia de Lange syndrome and evaluation of genotype-phenotype correlations. Am J Hum Genet 2004; 75: 610-623.

11 Pehlivan D, Hullings M, Carvalho CMB et al. NIPBL rearrangements in Cornelia de Lange syndrome: evidence for replicative mechanism and genotype-phenotype correlation. Genet Med Off J Am Coll Med Genet 2012; 14: 313-322.

12 Selicorni A, Russo S, Gervasini C et al. Clinical score of 62 Italian patients with Cornelia de Lange syndrome and correlations with the presence and type of NIPBL mutation. Clin Genet 2007; 72: 98-108.

13 Braunholz D, Obieglo C, Parenti I et al. Hidden mutations in cornelia de lange syndrome limitations of sanger sequencing in molecular diagnostics. Hum Mutat 2015; 36: 26-29.

14 Gervasini C, Parenti I, Picinelli C et al. Molecular characterization of a mosaic NIPBL deletion in a Cornelia de Lange patient with severe phenotype. Eur J Med Genet 2013; 56: $138-143$. 
15 Castronovo P, Delahaye-Duriez A, Gervasini C et al. Somatic mosaicism in Cornelia de Lange syndrome: a further contributor to the wide clinical expressivity? Clin Genet 2010; 78: $560-564$.

16 Baquero-Montoya C, Gil-Rodríguez MC, Braunholz D et al. Somatic mosaicism in a Cornelia de Lange syndrome patient with NIPBL mutation identified by different next generation sequencing approaches. Clin Genet 2014; 86: 595-597.

17 Ansari M, Poke G, Ferry Q et al. Genetic heterogeneity in Cornelia de Lange syndrome (CdLS) and CdLS-like phenotypes with observed and predicted levels of mosaicism. $J$ Med Genet 2014; 51: 659-668.

18 Slavin TP, Lazebnik N, Clark DM et al. Germline mosaicism in Cornelia de Lange syndrome. Am J Med Genet A 2012; 158A: 1481-1485.

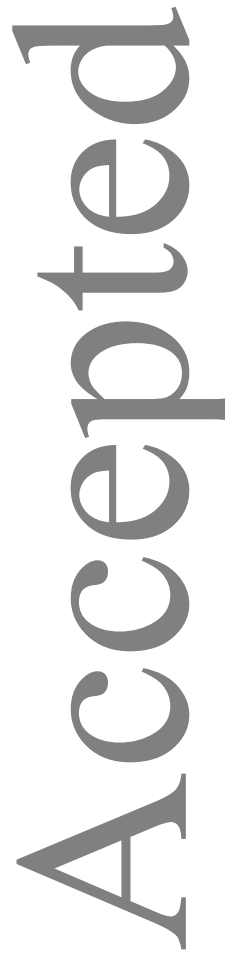




\section{TABLE LEGEND}

Table 1. Molecular and clinical features of thirty-eight patients presenting with Cornelia de Lange syndrome. (F: female, M: male, NA: not available, SD: standard deviation, TOP: termination of pregnancy). Nucleotide numbering reflects cDNA numbering with +1 corresponding to the A of the ATG translation initiation codon in the reference sequence, according to journal guidelines (www.hgvs.org/mutnomen). The initiation codon is codon 1. Concerning clinical features, stature is represented as standard deviation compared to standard healthy population. Feeding difficulties are noticed as moderate when there is an impact on growth but without medical assistance; otherwise enteral nutrition device is indicated. Gastro-enteral reflux disease is considered as severe when a sugery was performed. Intellectual disability is represented according to OMS classification namely mild for IQ 55 to 70, moderate for IQ 40 to 55 and severe for IQ below 40. Facial dysmorphism is considered as classical when the diagnosis is obvious including fine arched eyebrows, synophris, long eyelashes, thin upper lip and anteverted nares. 


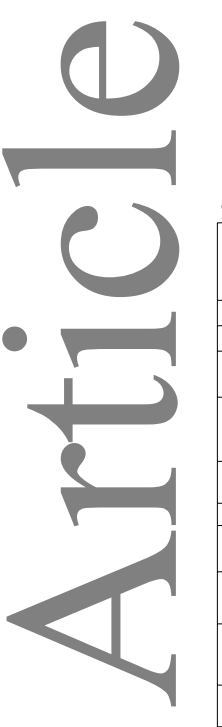

Table 1. Molecular and clinical features of 38 novel patients presenting with Cornelia de Lange syndrome.

\begin{tabular}{|c|c|c|c|c|c|c|c|c|c|c|c|c|c|c|c|c|c|c|}
\hline Patient & Gender & $\begin{array}{c}\text { Nucleotide } \\
\text { mutation }\end{array}$ & Protein mutation & $\begin{array}{l}\text { Exon/ } \\
\text { intron }\end{array}$ & Parents & Sample & Age & $\begin{array}{c}\text { Intrauterine } \\
\text { growth } \\
\text { failure }\end{array}$ & $\begin{array}{c}\text { Feeding } \\
\text { difficulties }\end{array}$ & $\begin{array}{c}\text { Gastro- } \\
\text { oesophag } \\
\text { eal reflux }\end{array}$ & $\begin{array}{c}\text { Limb } \\
\text { abnormalities }\end{array}$ & Malformations & $\begin{array}{c}\text { Short } \\
\text { stature }\end{array}$ & Microcephaly & $\begin{array}{c}\text { Intellectual } \\
\text { disability }\end{array}$ & $\begin{array}{c}\text { Behaviour } \\
\text { trouble }\end{array}$ & Deafness & $\begin{array}{c}\text { Facial } \\
\text { dysmorphism }\end{array}$ \\
\hline 1 & $\mathrm{~F}$ & $\begin{array}{l}\text { c.5_12delins11 } \\
\end{array}$ & $\begin{array}{l}\text { p.Asn2Lysfs*18 } \\
\end{array}$ & exon 2 & $\mathrm{NA}$ & leukocytes & 23 years & $\mathrm{NA}$ & $\mathrm{NA}$ & yes & pes cavus & aortic stenosis & $-5 \mathrm{SD}$ & $\mathrm{NA}$ & moderate & severe & $\mathrm{NA}$ & $\begin{array}{ll}\text { classical } \\
\end{array}$ \\
\hline 2 & $\mathrm{~F}$ & c.19del & p.His7Metfs*19 & exon 2 & $\mathrm{NA}$ & buccal cells only & 6 years & $<-3$ DS & moderate & $\mathrm{NA}$ & brachymetacarpy I & $\mathrm{NA}$ & $-2 \mathrm{SD}$ & $-2 \mathrm{SD}$ & moderate & moderate & yes & $\mathrm{NA}$ \\
\hline 3 & $\mathrm{~F}$ & c.143_147del & p.Glu48Glyfs*8 & exon 3 & de novo & leukocytes & 2 months & $\mathrm{NA}$ & $\mathrm{NA}$ & $\mathrm{NA}$ & $\begin{array}{l}\text { distal phalanges } \\
\text { hypoplasia }\end{array}$ & diaphragmatic hernia & $\mathrm{NA}$ & $<-3 \mathrm{SD}$ & mild & absent & $\mathrm{NA}$ & $\mathrm{NA}$ \\
\hline 4 & $\mathrm{~F}$ & c.275del & p.Ile92Asnfs $* 30$ & exon 4 & de novo & leukocytes & 6 years & $<-3 \mathrm{DS}$ & $\begin{array}{c}\text { enteral } \\
\text { nutrition }\end{array}$ & severe & brachymetacarpy I & $\begin{array}{l}\text { atrial septal defect, aortic } \\
\text { coarctation, bifid turerus, , Pierre } \\
\text { Robin sequence }\end{array}$ & $<-3 \mathrm{SD}$ & $-4 \mathrm{SD}$ & moderate & absent & NA & classical \\
\hline 5 & м & c.403del & p.Ser135Valfs*81 & exon 5 & $\mathrm{NA}$ & tissue & TOP at $20 \mathrm{GW}$ & $<-2$ DS & - & - & limb defects & $\begin{array}{l}\text { tetralogy of Falot, Pierre Robin } \\
\text { sequence }\end{array}$ & - & absent & - & - & - & classical \\
\hline 6 & $\mathrm{~F}$ & c.1342 insC & p.Pro448Profs*19 & exon 9 & de novo & tissue & TOP at $32 \mathrm{GW}$ & $<-3 \mathrm{SD}$ & - & - & limb defects & diaphragmatic hernia & - & absent & - & - & - & classical \\
\hline 7 & м & c.1821_1824del & p.Glu607Aspfs*6 & exon 10 & de novo & lung tissue & TOP at $24 \mathrm{GW}$ & $<-3$ SD & - & - & brachymetacarpy I & $\begin{array}{l}\begin{array}{l}\text { diaphragmatic hernia, } \\
\text { hypospadias }\end{array} \\
\end{array}$ & - & absent & - & - & - & classical \\
\hline 8 & м & c. $1984 \mathrm{~A}>\mathrm{T}$ & p.Lys662* & exon 10 & de novo & leukocytes & 3 years & $-3 \mathrm{SD}$ & $\begin{array}{c}\begin{array}{c}\text { enteral } \\
\text { nutrition }\end{array} \\
\end{array}$ & yes & limb defects & $\begin{array}{l}\text { Pierre Robin sequence, } \\
\text { cryptorchidy }\end{array}$ & $-2 \mathrm{SD}$ & $-6 \mathrm{SD}$ & severe & absent & yes & classical \\
\hline 9 & M & c.2178del & p.Lys726Asnfs*68 & exon 10 & de novo & tissue & TOP at $31 \mathrm{GW}$ & $<-2$ DS & - & - & $\begin{array}{c}\text { brachymetacarpy I, } \\
\text { phalanges } \\
\text { hypoplasia }\end{array}$ & ventricular septal defect & - & $-2 \mathrm{SD}$ & - & - & - & classical \\
\hline 10 & м & c.2259del & p.Arg754Aspfs*40 & exon 10 & de novo & tissue & TOP at $25 \mathrm{GW}$ & $<-2$ DS & - & - & $\begin{array}{l}\text { brachymetacarpy I, } \\
\text { ectrodactyly }\end{array}$ & absent & - & $-2 \mathrm{SD}$ & - & & - & classical \\
\hline 11 & м & c.2412_2413delinsGA & p.Pro805Thrf* $* 10$ & exon 10 & de novo & leukocytes & 6 months & $<-3$ SD & $\begin{array}{c}\begin{array}{c}\text { enteral } \\
\text { nutrition }\end{array} \\
\end{array}$ & yes & ectrodactyly & hypospadias & $-4 \mathrm{SD}$ & -4 SD & moderate & absent & yes & moderate \\
\hline 12 & $\mathrm{M}$ & $\begin{array}{l}\text { c.2773_2774del } \\
\end{array}$ & $\begin{array}{l}\text { p.Lys925 } \\
0.11105 \\
\end{array}$ & exon 10 & NA & $\begin{array}{l}\text { leukocytes } \\
\text { loukhoctos }\end{array}$ & 13 years & $\begin{array}{ll}\frac{c}{<-3} \mathrm{SD} \\
<-2 \mathrm{SD} \\
\end{array}$ & moderate & $\mathrm{NA}$ & limb defects & $\begin{array}{l}\text { hypospadias, cryptorchidy } \\
\text {. }\end{array}$ & $\begin{array}{l}-8 \mathrm{SD} \\
<2 \mathrm{SD}\end{array}$ & $\begin{array}{l}-6 \mathrm{SD} \\
-2 \mathrm{SD}\end{array}$ & severe & absent & $\mathrm{NA}$ & $\begin{array}{c}\text { classical } \\
\text { chascical }\end{array}$ \\
\hline 13 & $\begin{array}{l}\mathrm{F} \\
\mathrm{M}\end{array}$ & $\begin{array}{lc}\text { c.3172_3184del } \\
\end{array}$ & $\begin{array}{l}\text { p.Glu1058Prc } \\
\text { p.Arg1 106* }\end{array}$ & $\frac{e x o n 11}{\text { exon } 12}$ & $\begin{array}{l}\text { Father NA } \\
\text { de novo }\end{array}$ & leukocytes & 9 months & $\frac{<-2 \mathrm{SD}}{2 \mathrm{SD}}$ & $?$ & $\mathrm{NA}$ & $\mathrm{NA}$ & $\mathrm{NA}$ & $<-2 \mathrm{SD}$ & $<-2$ SD & $\mathrm{NA}$ & $\mathrm{NA}$ & $\mathrm{NA}$ & classical \\
\hline 14 & & $c .3316 \mathrm{C}>\mathrm{T}$ & p.Arg1 106* & exon 12 & de novo & leukocytes & 2,5 years & $-2 \mathrm{SD}$ & moderate & yes & brachymetacarpy I & NA & absent & absent & $\begin{array}{l}\text { mild } \\
\end{array}$ & absent & $\mathrm{NA}$ & $\mathrm{NA}$ \\
\hline 15 & NI & $c .3439 \mathrm{C}>\mathrm{T}$ & p.Arg1 147* & exon 12 & de novo & tissue & TOP at $14 \mathrm{GW}$ & absent & - & - & limb defects & $\begin{array}{l}\text { dappraganatic nenia, } \\
\text { ventricular septat defect, cleft } \\
\text { palate }\end{array}$ & $\cdot$ & . & . & - & - & $\mathrm{NA}$ \\
\hline 16 & м & $c .3445 \mathrm{C}>\mathrm{T}$ & p.Arg1 149* & exon 12 & de novo & leukocytes & 13 years & $<-3 \mathrm{SD}$ & $\begin{array}{c}\text { enteral } \\
\text { nutrition }\end{array}$ & $\mathrm{NA}$ & limb defects & cardiac defect, hypospadias & $-4 \mathrm{SD}$ & $<-3$ SD & moderate & severe & yes & classical \\
\hline 17 & M & $\begin{array}{l}\text { c.4020_4024delinsAG } \\
\text { TGTA }\end{array}$ & p.Lys1341 Valfs* 13 & exon 17 & $\mathrm{NA}$ & buccal cells only & 18 months & absent & absent & absent & brachydactyly & $\begin{array}{l}\text { micropenis, cryptorchidy, } \\
\text { pyelo ureteral duplication }\end{array}$ & $\mathrm{NA}$ & $-2 \mathrm{SD}$ & mild & mild & yes & classical \\
\hline 18 & $\mathrm{~F}$ & c.6516_6517insA & p.Val2173Serfs*3 & exon 38 & de novo & leukocytes & 8 years & $-3 \mathrm{SD}$ & moderate & yes & Clinodactyly V & & $-2 \mathrm{SD}$ & $-4 \mathrm{SD}$ & moderate & mild & absent & classical \\
\hline 19 & м & $c .6694 \mathrm{C}>\mathrm{T}$ & p.Gln2232* & exon 39 & de novo & leukocytes & 2 years & $<-3 \mathrm{SD}$ & $\begin{array}{c}\begin{array}{c}\text { enteral } \\
\text { nutrition }\end{array} \\
\text { nat }\end{array}$ & yes & limb defects & $\begin{array}{l}\text { hypospadia, cryptorchidy, } \\
\text { ventricular septal defect }\end{array}$ & $<-8 \mathrm{SD}$ & $<-8$ SD & severe & absent & absent & moderate \\
\hline 20 & $\mathrm{~F}$ & c.6987_6994delinsA & p.Asp2329Glufs* ${ }^{*} 15$ & exon 41 & $\mathrm{NA}$ & leukocytes & 1 year & $<-2$ SD & $\begin{array}{c}\begin{array}{c}\text { enteral } \\
\text { nutrition }\end{array} \\
\end{array}$ & yes & moderate & $\mathrm{NA}$ & $<-2 \mathrm{SD}$ & $\mathrm{NA}$ & severe & severe & $\mathrm{NA}$ & classical \\
\hline 21 & F & c.7969delinsTC & p.Gly2657Serfs*4 & exon 46 & de novo & $\begin{array}{l}\text { leukocytes and } \\
\text { buccal cells }\end{array}$ & 18 months & $-3 \mathrm{SD}$ & moderate & yes & brachymetacarpy I & $\mathrm{NA}$ & $-2 \mathrm{SD}$ & $-2.5 \mathrm{SD}$ & moderate & absent & yes & classical \\
\hline 22 & M & c.8275_8276dup & p.Leu2759Leufs*6 & exon 47 & de novo & leukocytes & 6 years & absent & $\begin{array}{c}\text { enteral } \\
\text { nutrition }\end{array}$ & severe & absent & absent & $-2 \mathrm{SD}$ & $-2 \mathrm{SD}$ & moderate & mild & absent & moderate \\
\hline 23 & $\mathrm{~F}$ & $c .8361$ insA & p.Val2788Metfs*32 & exon 47 & $\mathrm{NA}$ & leukocytes & 7 years & $\mathrm{NA}$ & moderate & $\mathrm{NA}$ & $\mathrm{NA}$ & $\mathrm{NA}$ & $\mathrm{NA}$ & $<-2$ SD & mild & absent & $\mathrm{NA}$ & $\mathrm{NA}$ \\
\hline 24 & $\mathrm{~F}$ & $c .8377 \mathrm{C}>\mathrm{T}$ & p.Arg2793* & exon 47 & $\mathrm{NA}$ & leukocytes & 4 years & $<-3 \mathrm{SD}$ & absent & absent & $\begin{array}{l}\text { distal phalanges } \\
\text { hyppoplasia }\end{array}$ & absent & $-3 \mathrm{SD}$ & $-4 \mathrm{SD}$ & mild & absent & $\mathrm{NA}$ & moderate \\
\hline 25 & $\mathrm{~F}$ & $c .64+2 \mathrm{~T}>\mathrm{A}$ & $\begin{array}{l}\text { skipping ATG } \\
\text { initiation codon }\end{array}$ & intron 2 & Father NA & leukocytes & 3 years & $-2 \mathrm{SD}$ & moderate & yes & syndactyly & absent & $-3.5 \mathrm{SD}$ & -4 DS & mild & absent & yes & moderate \\
\hline 26 & M & $c .358+1 \mathrm{G}>\mathrm{A}$ & unknown & intron 4 & $\mathrm{NA}$ & buccal cells only & 14 years & $<-2$ SD & moderate & yes & brachymetacarpy I & cryptorchidy & $\mathrm{NA}$ & $<-2$ SD & moderate & absent & yes & $\mathrm{NA}$ \\
\hline 27 & M & c.772-7_772-4delinsA & p.Asp258Tyrfs*13 & intron 7 & de novo & tissue & TOP at $23 \mathrm{GW}$ & $<-2$ SD & - & - & brachydactyly & $\begin{array}{l}\text { ventral septal defect, cystic } \\
\text { kydneys }\end{array}$ & - & absent & - & - & - & classical \\
\hline 28 & M & c.5225_5225+4del & unknown & intron 26 & $\mathrm{NA}$ & $\begin{array}{l}\text { leukocytes and } \\
\text { buccal cells }\end{array}$ & 3 months & $<-2$ SD & moderate & $\mathrm{NA}$ & $\begin{array}{l}\text { brachydact yly, } \\
\text { syndact yly }\end{array}$ & micropenis & $<-2 \mathrm{SD}$ & $<-3$ SD & moderate & $\mathrm{NA}$ & yes & classical \\
\hline 29 & $\mathrm{~F}$ & $c .5329-1.1$ & p.. & intron 27 & $\mathrm{NA}$ &  & 10 years & $\mathrm{N}$ & $\mathrm{abs}$ & absent & & $\mathrm{N} / \mathrm{T}$ & no & -3 & $\mathrm{~N}$ & $\mathrm{NA}$ & $\frac{\mathrm{NA}}{\mathrm{N}}$ & moder \\
\hline 30 & $\mathrm{M}$ & c.5329-15A & p.lle1777_Arg1809del & 27 & de novo & leukocy & years & $<-3 \mathrm{SD}$ & absent & $\mathrm{NA}$ & & $\mathrm{NA}^{\mathrm{N}}$ & $-3 \mathrm{SD}$ & $-4 \mathrm{SD}$ & mild & bse & $\mathrm{NA}$ & $\mathrm{NA}$ \\
\hline 31 & $\mathrm{~F}$ & c. $6250-1 \mathrm{G}>\mathrm{A}$ & unknown & intron 35 & de novo & leukocytes & 21 months & $<-3 \mathrm{SD}$ & $\begin{array}{c}\text { enteral } \\
\text { nutrition }\end{array}$ & $\mathrm{NA}$ & $\begin{array}{c}\text { brachymetacarpy I, } \\
\text { phalanges } \\
\text { hypoplasia }\end{array}$ & Pierre Robin sequence & $-4 \mathrm{SD}$ & $-6 \mathrm{SD}$ & moderate & absent & yes & classical \\
\hline 32 & M & c.80_89delins16 & $\begin{array}{l}\text { p.Pro27_Pro29delins } \\
\text { LeuGinLeuProAsn } \\
\end{array}$ & exon 3 & de novo & leukocytes & 18 months & $<-3 \mathrm{SD}$ & $\begin{array}{c}\text { enteral } \\
\text { nutrition }\end{array}$ & absent & $\begin{array}{l}\text { Brachydactyly, } \\
\text { clinodactyly V }\end{array}$ & pulmonar stenosis, cryptorchidy & $-5 \mathrm{SD}$ & $-4 \mathrm{SD}$ & moderate & absent & absent & moderate \\
\hline 33 & M & $\begin{array}{ll}c .6148 \mathrm{~A}>\mathrm{T} \\
\end{array}$ & p.Ile2050Phe & exon 35 & Father NA & leukocytes & 19 years & $<-3 \mathrm{SD}$ & $\begin{array}{l}\text { moderate } \\
\end{array}$ & severe & 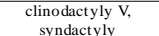 & micropenis, cryptorchidy & $\mathrm{NA}$ & $<-3 \mathrm{SD}$ & severe & absent & $\mathrm{NA}$ & $\mathrm{NA}$ \\
\hline 34 & $\mathrm{~F}$ & c.622 & p. & $\frac{e x}{x}$ & $d e$ & leukocytes & 14 years & -2 & absent & absent & brachy & $\mathrm{NA}$ & absent & $-2,5 \mathrm{SD}$ & mild & absent & $\mathrm{NA}$ & oderate \\
\hline 35 & $\mathrm{M}$ & c.627 & Th & exon 36 & de novo & tissue & TOP at $15 \mathrm{GW}$ & absent & & & limb defects & abss & & no & & & & moderate \\
\hline 36 & $\mathrm{~F}$ & c.6 & p.Le & 37 & $\mathrm{~N}_{t}$ & leukocy & 1 & 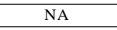 & $\mathrm{NA}$ & $\mathrm{NA}$ & $\mathrm{NA}$ & $\mathrm{NA}$ & $\mathrm{N}$ & $\mathrm{N}$ & $\mathrm{NA}$ & $\mathrm{NA}$ & $\mathrm{NA}$ & $\mathrm{NA}$ \\
\hline 37 & $M$ & & & 40 & ovo & ies & 20 years & $<-3 \mathrm{SD}$ & $\mathrm{NA}$ & $\mathrm{NA}$ & ymetacarpy I & ilar septal & $-4 \mathrm{SD}$ & -2 & mild & moderate & $\mathrm{NA}$ & $\mathrm{NA}$ \\
\hline 38 & M & c.7012G>C & p.Ala2338Pro & exon 41 & de novo & $\begin{array}{l}\text { leukocytes } \\
\end{array}$ & 24 years & $\mathrm{NA}$ & $\mathrm{NA}$ & yes & camptodactyly & $\mathrm{NA}$ & absent & $-2 \mathrm{SD}$ & noderate & absent & $\mathrm{NA}$ & noderate \\
\hline
\end{tabular}

